Proposals have been developed to address these issues, in particular by differentiating administrative liability for these acts, creating a clear list of regulations, violation of which may result in administrative liability for such acts, as well as the introduction of relevant prohibitions in strict accordance with the Constitution of Ukraine, in particular after introduction of a state of emergency or making appropriate amendments to the Basic Law of the Ukrainian state.

Keywords: administrative liability, quarantine, coronavirus, administrative offense, infectious diseases, rules of quarantine of people.

DOI: $10.33766 / 2524-0323.92 .233-244$

УДК 342.95:332.87

Ю. В. Тарасюк, заслужений юрист України, перший заступник директора КП «Житлоінвестбуд - УКБ»

(м. Київ, Україна)

e-mail: tarasyuk_y@ukr.net

iDhttps:/ / orcid.org/0000-0001-8352-7120

\title{
ГЕНЕЗА АДМІНІСТРАТИВНО-ПРАВОВОГО ЗАБЕЗПЕЧЕННЯ ЖИТЛОВОГО БУДІВНИЦТВА В УКРАЇНІ (3 ЧАСІВ ІСНУВАННЯ СРСР І ДО СЬОГОДНІ)
}

Стаття присвячена здійсненню історико-правового аналізу становлення та розвитку адміністративно-правового забезпечення житлового будівнищтва в Україні 3 часів існування СРСР в і до сьогодні. Обгрунтовано, що за роки панування в Україні радянського режиму було сформовано досить розгалужену систему нормативно-правових актів із питань будівнищтва, що складалася із загальносоюзних та республіканських актів, деякі з яких $є$ і досі чинними. Під час аналізу сучасного етапу розвитку адміністративно-правового забезпечення будівельної сфері було з'ясовано, що основним питанням, яке слід вирішити законодавцю, є забезпечення здійснення систематизації законодавства у вказаній сфері, з метою його приведення у єдину, злагоджену систему з чітко виз наченим стрижневим галузевим Законом.

Ключові слова: історико-правовий аналіз, становлення, розвиток, адміністративно-правове забезпечення, житлове будівництво, СРСР, незалежність, Україна.

Постановка проблеми. Однією з надзвичайно важливих умов нормального існування людини є житло, наявність та стан якого в значній мірі обумовлює рівень їі благополуччя, задоволеності життям. Тож існуючі в Україні проблеми у сфері житлового будівництва, а також прогалини в науково-теоретичному підгрунті цієї проблематики обумовлюють актуальність та доцільність проведення комплексного дослідження адміністративно-правового забезпечення житлового будівництва. Вбачається за доцільне вивчити генезу зазначених засад, оскільки з'ясування та аналіз історико-правових аспектів їх виникнення, становлення і розвитку дозволяє уникнути повторення помилок минулого та сприяє визначенню перспектив подальшого удосконалення й розвитку адміністративно-правового забезпечення житлового будівництва в Україні.

(C) Тарасюк Ю. В., 2020 
Аналіз останніх досліджень і публікацій. Цілком підтримуючи прагнення держави, в особі їі кометних органів і посадових осіб, до вдосконалення та розвитку вітчизняної сфери житлового будівнищтва, вважаємо за необхідне зазначити, що для забезпечення якісного та змістовного підходу до вирішення цього питання, необхідно сформувати відповідне науково-теоретичне підгрунтя. Зауважимо, що проблеми житлового будівництва досліджували у своїх працях: С. А. Ушацький, А. В. Сердюк, М. В. Гарат, Е. О. Дідоренко, К. С. Борисова, О. О. Квасніцька, Л. К. Воронов, В. В. Омельчук, О. І. Удовиченко, Б. П. Андресюк, Л. В. Кузьменко, В. І. Теремецький та інші науковці. Однак, віддаючи належне науковому внеску цих та інших дослідників у розробку проблематики житлового будівництва, слід зазначити, що більшість досліджень у цій сфері є застарілими і значною мірою втратили свою актуальність.

Так С. А. Ушацький та А. В. Сердюк у своєму науковому дослідженні вказують, що проблема житлового будівництва є однією з найбільш важливих для розвитку суспільства, оскільки призводить до зниження рівня життя населення, поширення бідності, зростання міграції, депопуляції населення та погіршення якості людських ресурсів загалом [1, с. 4]. У своїй науковій праці автори аналізують розвиток розвитку ринку доступного житла на початку 2000-х років.

М. В. Гарат, розмірковуючи про генезу містобудівного законодавства України, вказує, що з моменту проголошення незалежності Україна пройшла чималий шлях розвитку. На першому закладено основи адміністративно-правового регулювання сфери планування та забудови територій через ухвалення відповідних законів та підзаконних нормативно-правових актів. Другий етап генезису адміністративно-правового регулювання сфери планування та забудови територій обумовлений світовою фінансовою кризою 2008-2009 рр., у зв' язку з чим на законодавчому рівні визначено шляхи подолання кризових явищ у будівельній галузі. На третьому етапі, на думку автора, набули чинності нові державні будівельні норми, а законодавство в галузі будівництва розроблялося з метою забезпечення сприятливих умов ведення бізнесу, розвитку будівельної та суміжних галузей через удосконалення дозвільних та погоджувальних процедур у будівництві, адаптацію регуляторної політики України до європейських стандартів [2, с. 111].

Зміст житлової проблематики, зауважує О. С. Аврамова, пов'язаний із тим, що від задоволення житлової потреби залежить рівень життя людини, можливість iї морального та фізичного розвитку, оскільки житло виконує соціальну, економічну, біологічну функцію [3, с. 26]. В. І. Теремецький у своїй публікації розглядає проблеми адміністративно-правового забезпечення оподаткування житлової нерухомості та формулює пропозиції з його удосконалення [4].

Отже, управлінські аспекти забезпечення права на житло, зокрема адміністративно-правові засади житлового будівництва, у науковій літературі висвітлюються фрагментарно, у контексті розв'язання інших проблемних питань, тому комплексний підхід до вивчення цієї проблематики наразі відсутній.

Формулювання цілей. Метою статті є здійснення історико-правового аналізу становлення і розвитку адміністративно-правового забезпечення житлового 
будівництва в Україні за часів існування СРСР і дотепер. Основне завдання - проаналізувати законодавство у сфері житлового будівництва, яке існувало за часів СРСР і незалежної України, та здійснити його доктринальну оцінку.

Виклад основного матеріалу. Як відомо, становлення та розвиток адміністративно-правового забезпечення житлового будівництва в Україні тісно пов'язаний із встановленням та пануванням на території нашої держави радянського режиму. На розвиток державної політики щодо забезпечення прав громадян на житло суттєво впливала ідеологія політичного режиму, стан прав людини у державі. Аналіз нормативних актів, стверджує О. Є. Аврамова, проблема забезпечення житлом (зокрема якісним житлом) спочатку розглядалася як проблема доброчинності, потім це стало одним із питань розвитку економіки. Зі зміною політичного устрою держави у 1917 р. житлова потреба стала соціальною справою, а згодом_одним із питань економіки [3, с. 26].

Однією із суттєвих особливостей розвитку засад житлового будівництва в радянській період була відсутність можливості приватного будівництва. Так 20.08.1918 p. було видано Декрет Всеросійського Центрального Виконавчого комітету «Про скасування права приватної власності на нерухомості у містах» [5, с. 13]. У ст. 1 цього акта проголошувалося, що скасовується право приватної власності на всі без винятку ділянки, як забудовані, так і не забудовані, як належні приватним особам і промисловим підприємствам, так і відомствам та установам, що знаходяться в межах всіх міських поселень [6]. 31917 по 1923 рр. у СРСР створювалися санітарні норми устрою й утримання житла. У період НЕПу були відмінені принципи житлового розподілу [7]. Скасувавши можливість приватного будівництва, радянська влада запровадила таку форму участі громадян у житловому будівництві, як житлово-будівельні кооперативи. Так ЦВК СРСР, РНК СРСР було прийнято постанову «Про житлову кооперацію» від 19.08.1924 р., у якій зазначалося, що з метою боротьби з житловою кризою, шляхом розвитку житлового будівництва та сприяння найбільш господарському використанню наявних житлових будівель на засадах самодіяльності широких мас трудящого населення, Центральний Виконавчий Комітет і Рада Народних Комісарів Союзу РСР постановляють: Громадянам Союзу РСР для задоволення житлової потреби дозволяється добровільно об'єднуватися в житлові кооперативні товариства на підставах, викладених у статтях цієї Постанови. Житлові кооперативні товариства поділяються на: а) житлово-орендні кооперативні товариства; б) робочі житлово-будівельні кооперативні товариства; в) загальногромадянські житлово-будівельні кооперативні товариства [8].

Органами управління житлово-кооперативних товариств усіх видів, відповідно до вказаної Постанови, є загальні збори членів товариства і його правління, яке обирається загальними зборами. Кожне житлово-кооперативне товариство обирає також ревізійну комісію. Житлово-кооперативні товариства всіх видів можуть об'єднуватися в єдині міські та губернські (і відповідні їм) союзи житлової кооперації. Останні можуть об'єднуватися з дозволу економічних нарад відповідних республік в союзи житлової кооперації в масштабі союзних республік. У великих містах, крім міських спілок, можуть бути утворених районні союзи житлової коо- 
перації. Органами управління спілок усіх ступенів є збори уповноважених від організацій, які входять до їх складу й обираються зборами уповноважених правління; органами контролю є ревізійні комісії. Правом обирати і бути обраними в усі органи управління і контролю спілок всіх ступенів користуються тільки уповноважені особи, що володіють виборчим правом [8].

Також слід виокремити Постанову ЦВК СРСР, РНК СРСР від 04.01.1928 p. «Про житлову політику», у якій зазначалося, що незважаючи на те, що прийнятими за останні три роки заходами в ряді великих промислових центрів досягнуто деяке поліпшення житлового становища робітників, стан житлової справи на всій території Союзу РСР продовжує залишатися важким. Надаючи важливе значення будівництву робочого житла і поліпшенню загального стану житлового та комунального господарства, Центральний Виконавчий Комітет і Рада Народних Комісарів Союзу РСР визнали за необхідне для вирішення житлової кризи: 1) посилення темпу будівництва нового житла; 2) максимальне накопичення коштів всередині самого житлового господарства, зокрема за рахунок квартирної плати; 3) правильну і доцільну постановку управління і визискування житлового фонду; 4) зміцнення і розвиток кооперативного житлового будівництва; 5) можливо більше залучення приватного капіталу в житлове будівництво; 6) впорядкування організації житлового будівнищтва і його здешевлення [9; 3, с. 28].

3 метою вирішення зазначених завдань, Центральний Виконавчий Комітет і Рада Народних Комісарів Союзу РСР визначили засади відновлення існуючих житлових приміщень та розвитку нового житлового будівнищтва; міри по збереженню існуючого житлового фонду; завдання союзних республік $з$ управління житловим фондом та його експлуатації тощо [9]. На виконання поставлених у вказаній Постанові засад було прийнято ще декілька нормативно-правових актів з окремих питань забезпечення житлового будівництва. Зокрема, таким актом стала Постанова РНК СРСР від 17.04.1928 р. (в ред. від 14.09.1928 р.) «Про заходи заохочення будівництва житла за рахунок приватного капіталу», яка передбачала певні пільги громадянам і приватним юридичним особам Союзу РСР, що здійснює це будівництво [10]. Нормування в будівництві здійснювалося положеннями «Зводу виробничих будівельних норм» (1927-1930 рр.). Цей Звід норм є результатом докорінного перегляду, який являє собою «Урочне положення на всі загальні роботи, що проводяться при фортецях, державних будівлях і гідротехнічних спорудах» від 1832 р. [11]. У 1938 р. РНК СРСР приймає постанову № 233 «Про покращення проектної та кошторисної справи та про упорядкування фінансування будівнищтва» [12]. До цієї постанови додавалися: «Інструкції зі складання проектів і кошторисів 3 промислового будівництва», «Правилами фінансування будівництва промисловим банком», «Правилами про підрядні договори з будівництва». Довоєнний період регулювання будівельної сфери в СРСР загалом та Україні зокрема, зазначає О. О. Квасніцька, характеризувався значною кількістю відомчих норм і технічних умов, мало погоджених одні з одними i «засмічених» приватними рекомендаціями, практика проектування складалася хаотично, відповідальність залишалася неврегульованою [13, с. 375].

Слід зауважити, що в Конституціях Української СРС 1919 та 1929 рр. взагалі 
не йдеться про право громадян на житло та його забезпечення державою. У Конституції Української РСР 1937 р. уже закріплювалося, що право особистої власності громадян на їх трудові прибутки та заощадження, на житловий будинок і підсобне хатнє господарство, на предмети хатнього господарства і вжитку, на предмети особистого споживання та комфорту, так само як право спадкування особистої власності громадян охороняються законом. Також у Основному законі встановлювалося, що до відання УРСР в особі їі найвищих органів влади і органів державного управління належать, окрім іншого, керування житловим і комунальним господарством, житловим будівництвом і впорядкуванням міст та інших населених місцевостей [14].

Посилену увагу саме житловому будівництву радянська влада починає приділяти в 50-ті pp. XX ст. Розвивалася домобудівельна індустрія, відбувалася концентрація будівельної справи, що сприяло зниженню собівартості будівельних робіт, скороченню термінів зведення житлових будівель. Архітектурне планування спрямовувалось на якнайшвидше вирішення житлової проблеми. Значно скоротилися строки та вартість житлового будівництва завдяки використанню типових проектів, впровадженню індустріального великоблочного, а потім великопанельного будівництва. Причому, у зв' язку з переселенням у капітальні будинки багатьох сімей, які раніше проживали в непридатних для життя приміщеннях та таких, що підлягали знесенню, тимчасових помешканнях барачного типу, обсяг нового житлового будівництва перевищував приріст житлового фонду. За ініціативою М. С. Хрущова в СРСР були вжиті рішучі заходи щодо здійснення житлового будівництва. Так, якщо в 1951-1955 рр. у містах і селищах у середньому за рік вводилось загальної житлової площі 30,4 млн кв. м, то в 1957 р. - уже 52 млн, а за 19591965 рр. - 715 млн кв. м. За 10 років (з 1955 по 1964 рр.) міський житловий фонд зріс на 80 \%. Лише за 1956-1960 рр. новосілля відсвяткували майже 54 млн громадян, або чверть населення країни. В Україні за 1951-1960 рр. було споруджено майже 3 млн квартир загальною (корисною) площею 129,5 млн кв. м; житло одержали 13,3 млн осіб [15, с. 169].

Важливими нормативно-правовими актами, що визначали правові засади радянського житлового будівнищтва у 50-60 pp. ХХ століття були: постанова ЦК КПРС і Ради Міністрів СРСР від 31.07.1957 р. № 931 «Про розвиток житлового будівництва в СРСР» [16], Постанова ЦК Компартії України і Ради Міністрів УРСР від 24.08.1957 p. № 988 [17], Постанова Ради Міністрів Української РСР від 30.04.1958 р. № 514 «Про затвердження Положення про житлово-будівельні колективи та індивідуальних забудовників у містах і селищах міського типу Української РСР» [18]. У вказаних нормативно-правових актах радянським керівництвом було поставлене завдання в найкоротші строки ліквідувати нестачу житла, забезпечити належні житлові умови всім трудящим. Значно збілышилися асигнування на житлове будівництво, а також на розвиток домобудівельних комбінатів та промисловості будівельних матеріалів. У постанові передбачалося також значне розширення місцевих джерел фінансування. Господарські керівники одержали право виділяти на житлове будівництво частину фондів підприємств, до 30 \% загальної суми надплано- 
вого прибутку та інші кошти, що, безумовно, розширювало можливості закріплення робітників, адже за тих умов житло було найсуттєвішим фактором залучення робочої сили [15, с. 169-170].

У квітні 1978 р. було ухвалено нову Конституцію України, у якій закріплювалося, що в користуванні громадян можуть бути ділянки землі, які надаються в установленому законом порядку для ведення підсобного господарства (включаючи тримання худоби і птиці), садівництва та городництва, а також для індивідуального житлового будівництва. Громадяни зобов'язані раціонально використовувати надані їм земельні ділянки. Держава і колгоспи сприяють громадянам у веденні підсобного господарства. Крім того, у ст. 42 Основного закону проголошувалося право громадян України на житло. Зокрема, вказувалося, що це право забезпечується розвитком й охороною державного і громадського житлового фонду, сприянням кооперативному та індивідуальному житловому будівництву, справедливим розподілом під громадським контролем жилої площі, яка надається в разі здійснення програми будівництва благоустроєних жител, а також невисокою платою за квартиру і комунальні послуги. Громадяни України повинні дбайливо ставитись до наданого їм житла [19].

Наступні важливі зрушення в напрямі розвитку правових (у тому числі й адміністративно-правових) засад забезпечення житлового будівництва в Україні стали 80-ті рр. XX століття. Так у червні 1981 р. були прийняті Основи житлового законодавства Союзу РСР і союзних республік, які є чинними і до сьогодні. У цьому Законі, окрім іншого, були визначені засади розподілу компетенщій Союзу РСР та Союзних Республік у галузі регулювання житлових відносин, визначені інші засади управління житловим фондом, встановлені правила участі громадських організацій, трудових колективів і громадян в управлінні державним громадським житловим фондом та в забезпеченні його схоронності тощо [20]. Про індивідуальне житлове будівництво У 1983 р. був прийнятий Житловий Кодекс Української РСР, завданням якого є регулювання житлових відносин із метою забезпечення гарантованого Конституцією СРСР і Конституцією Української РСР права громадян на житло, належного використання і схоронності житлового фонду, а також зміцнення законності в галузі житлових відносин [21, с. 170]. Окремий розділ цього Кодексу стосується питань Управління житловим фондом.

Отже, за роки панування в Україні радянського режиму було сформовано розгалужену систему нормативно-правових актів із питань будівництва, яка складалася із загальносоюзних та республіканських актів. У цих нормативно-правових актах визначалися вимоги щодо: планування та фінансування будівництва (зокрема, житлового), складання кошторисної документації; пожежної та санітарної безпеки; форм участі громадян у розвитку житлового фонду; системи та повноважень органів управління державним жилим фондом; відповідальності за порушення законодавства у сфері житлового будівництва. Частина з цих правових актів діє і сьогодні. Загалом цей період розвитку житлового будівництва є неоднозначним. 3 одного боку відбулася значна активізація житлово-будівельної індустpiї, що дозволило вирішити проблему забезпечення населення житлом, як новим, так і шляхом реконструкції старих будівель. 3 іншого - будівництво відбувалося 3 
огляду на потреби планової економіки і значно менше враховувало соціальні потреби населення. Республіканські ж акти, які повинні були розвивати положення загальносоюзних нормативно-правових документів з урахування особливостей умов життя та розвитку у відповідних регіонах, досить часто дублювали положення загальносоюзних.

Наступний важливий етап розвитку адміністративно-правового забезпечення житлового будівництва в Україні розпочався із проголошення незалежності України і триває до тепер. Слід зауважити, що деякі дослідники в межах цього періоду розвитку зазначених засад також виокремлюють самостійні етапи (стадії). Дотепер у сфері будівництва загалом і житлового зокрема прийнято чимало нормативно-правових актів. При тому ніяких змістовних заходів щодо упорядкування та систематизації зазначеного нормативно-правового матеріал не проводилося. Прийняття нових нормативно-правових актів у ряді випадків не супроводжувалося скасуванням попередніх, унаслідок чого виникли законодавчі колізії. За таких обставин розмежування етапів формування і розвитку законодавства у сфері житлового будівництва в незалежній Україні має умовний характер. Хоча вже минуло майже три десятиліття з моменту проголошення незалежності України, утім основоположні законодавчі акти з питань житлового будівництва залишаються чинними ще з радянських часів.

На шляху становлення і розвитку адміністративно-правового забезпечення житлового будівництва незалежної Україні було прийнято чимало законодавчих актів. Серед них закони України «Про основи містобудування» (1992 р.), «Про місцеве самоврядування в Україні» (1997 р.), Про архітектурну діяльність (1999 р.), «Про ліцензування певних видів господарської діяльності» (2002 р., втратив чинність), «Про підтвердження відповідності» (2001 р., втратив чинність), «Про акредитацію органів 3 оцінки відповідності» (2001 р.), «Про генеральну схему планування території України» (2002 р), «Про технічні регламенти та процедури оцінки відповідності» (2005, втратив чинність», «Про дозвільну систему у сфері господарської діяльності» (2005р.), «Про комплексну реконструкцію кварталів (мікрорайонів) застарілого житлового фонду» (2006 р.), «Про будівельні норми» (2009 р.), «Про регулювання містобудівної діяльності» «Про стандартизацію» (2014 р.), «Про стандарти, технічні регламенти та процедури відповідності», «Про технічні регламенти та оцінку відповідності» (2015 р.), «Про ліцензування видів господарської діяльності» (2015 р.) тощо. Окрім перелічених законів питання житлового будівництва регламентуються підзаконними актами різних рівнів, цілям прийняття і змісту яких буде присвячено окрему наукову публікацію.

Висновок. Таким чином, за роки незалежності прийнято чимало нормативно-правових актів різної юридичної сили, які були покликані визначити концептуальні та стратегічні засади розвитку житлового будівництва в Україні, встановити необхідні правові принципи та гарантії в цій сфері, врегулювати організаційно-управлінські та технічні аспекти здійснення зазначеного будівництва. Не заперечуючи важливості та не применшуючи значення проведеної роботи, зауважимо, що кожного разу, приймаючи нові важливі нормативно-правові акти з ма- 
теріальних та процедурних питань у галузі будівнищтва, українська влада наголошує на своєму прагненні забезпечити найбільш ефективний, дієвий, прозорий та зрозумілий механізм здійснення державного управління цією сферою. Однак на практищі все виглядає не так добре, оскільки нормотворення та організаційно-інституційні зміни відбуваються досить часто безсистемно, що призводить до появи законодавчих колізій, прогалин та інших недоліків, що не сприяє зміцненню режиму законності в досліджуваній сфері. За таких обставин одним із ключових питань, яке слід вирішити законодавцю, є забезпечення здійснення систематизації законодавства в будівельній сфері, з метою його приведення у єдину, злагоджену систему з чітко визначеним стрижневим галузевим Законом.

Підсумовуючи викладене, констатуємо, що адміністративно-правове забезпечення житлового будівництва має тривалу та своєрідну історію свого становлення й розвитку, обумовлену особливостями суспільно-політичних та економічних умов, у яких перебувала Україні. Наразі формування досліджуваного законодавства ще не завершено і цей процес характеризується наявністю низки проблемних моментів, що визначає необхідність подальшого науково-теоретичного вивчення окресленої проблематики.

\section{Використані джерела:}

1. Організаційно-економічні основи формування та розвитку ринку доступного житла: монографія / С. А. Ушацький, А. В. Сердюк. Вінниця : ВНТУ, 2010.186 с.

2. Гарат М. В. Генезис містобудівного законодавства України. Зовнішня торгівля: економіка, фінанси, право. 2019. № 5. C. 101-116. URL : http://nbuv.gov.ua/UJRN/uazt_2019_5_ 11\. (дата звернення: 11.11.2020)

3. Аврамова О. С. Історичні засади виникнення житлового права України. Вісник Луганського державного університету внутрішніх справ імені Е. О. Дідоренка. 2012. Вип. 4. С. 24-32. URL : http://nbuv.gov.ua/UJRN/Vlduvs_2012_4_5. (дата звернення: 11.11.2020)

4. Теремецький В. І. Проблеми правового забезпечення відносин у сфері оподаткування житлової нерухомості. Вчені записки Таврійського національного університету імені В. I. Вернадського. Серія : Юридичні науки. 2017. Т. 28 (67). № 1. С. 47-57.

5. Борисова К. С. Конституційні засади забезпечення права на житло в Украӥні : автореф. дис. ... канд. юрид. наук: 12.00.02. Київ, 2018. 20 с.

6. Декрет ВЦИК «Об отмене права частной собственности на недвижимость в городах» від 20.08.1918 p. URL : http://www.economics.kiev.ua/download/ZakonySSSR/data 04/tex17323.htm. (дата звернення: 11.11.2020)

7. Устав строительный, измененный по продолжениям 1876 и 1879 гг., с разъяснениями по решениям Уголовного кассационного департамента Правительствующего Сената и приложением циркуляров Министерства внутренних дел и позднейших узаконений. Изд. 3. [С.-Петербург]: Типография придв. книгопр. К. К. Ретгера, 1881. [2], 428, V с.; 17. URL : http://tehne.com/library/ustav-stroitelnyy-izdanie-trete-s-peterburg-1881. (дата звернення: 11.11.2020)

8. Постановление ЦИК СССР, СНК СССР от 19.08.1924 «О жилищной кооперации». URL : http://www.consultant.ru/cons/cgi/online.cgi?req=doc\&base=ESU\&n=3035\#047 581 929410741197. (дата звернення: 11.11.2020)

9. Постановление ЦИК СССР, СНК СССР от 04.01.1928 «О жилищной политике». URL : http://www.consultant.ru/cons/cgi/online.cgi?rnd=0F55ADDE8102A4094DDCB747A1 AD1A49\&req $=$ doc\&base $=$ ESU $\& n=14332 \&$ REFFIELD $=134 \&$ REFDST $=100010 \&$ REFDO $=11827 \&$ 
REFBASE=ESU\&stat=refcode\%3D10679\%3Bindex\%3D17\#1drqg7kv3lq. (дата звернення: 11. 11.2020)

10. Постановление СНК СССР от 17.04.1928 (в ред. от 14.09 .1928 р.) «О мерах поощрения строительства жилищ за счет частного капитала». URL : http://www.consul tant.ru/cons/cgi/online.cgi?rnd=0F55ADDE8102A4094DDCB747A1AD1A49\&req=doc\&base $=$ ESU $\& n=49115 \&$ REFFIELD $=134 \&$ REFDST $=100011 \&$ REFDOC $=11827 \&$ REFBASE $=$ ESU \&stat $=$ refcode\%3D19025\%3Bindex\%3D18\#2h6xj0lcv3g. (дата звернення: 11.11.2020)

11. Из истории развития сметного нормирования в России. URL : https://avis-me dia.com/informatsiya/stati/stroitelstvo-i-smetnoe-delo/tsenoobrazovanie-i-smetnoe-norm irovanie/iz-istorii-razvitiya-smetnogo-normirovaniya-v-rossii/. (дата звернення: 11.11.2020)

12. Постановление СНК СССР от 26.02.1938 № 233 «Об улучшении проектного исметного дела и об упорядочении финансирования строительства» (вместе с «Инструкцией по составлению проектов и смет по промышшенному строительству», «Правилами финансирования строительства промьшшенным банком», «Правилами о подрядных договоpax по строительству»). URL : http://www.consultant.ru/cons/cgi/online.cgi?rnd=0F55A DDE8102A4094DDCB747A1AD1A49\&req=doc\&base $=$ ESU \&n=32323\&REFFIELD $=134 \& R E$ FDST $=100004 \&$ REFDOC $=33841 \&$ REFBASE $=$ ESU\&stat $=$ refcode $\% 3 D 16876 \% 3$ Bindex $\% 3 D 11 \# 4$ xkc354aan8. (дата звернення: 11.11.2020)

13. Квасніцька О. О. Історичний розвиток та становлення будівельного законодавства у правовому досвіді України. Наукові праці Національного університету «Одеська юридична академія». 2012. T. 12. C. 370-382. URL : http://nbuv.gov.ua/UJRN/Nponyua_2012_12_39. (дата звернення: 11.11.2020)

14. Конституція (Основний Закон) Української Радянської Соціалістичної Республіки від 30.01.1937 p. URL: http:/ / gska2.rada.gov.ua/site/const/istoriya/1937.html. (дата звернення: 11.11.2020)

15. Тишківська Н. В. Особливості державного управління житловим будівництвом в УРСР (1950-1960 роки) / Стратегія реформування системи державного управління на засадах демократичного врядування : матері. наук.-практ. конф. за міжнар. участю (Киӥв, 31 трав. 2007 р.). У 4 т. Київ : Вид-во НАДУ, 2007. Т. 1. С. 169-171. (дата звернення: 11.11.2020)

16. Постановление ЦК КПСС, Совмина СССР от 31.07.1957 № 931 «О развитии жилищного строительства в СССР». URL : http:/ / docs.cntd.ru/document/765714291. (дата звернення: 11.11.2020)

17. Постанова ЦК Компартії України і Ради Міністрів УРСР від 24.08.1957 р. № 988. Зібрання постанов УРСР, 1957 р., № 12, ст. 154.

18. Постанова РМ Української РСР «Про затвердження Положення про житлово-будівельні колективи та індивідуальних забудовників у містах і селищах міського типу Української РСР» від 30.04.1958 № 514. URL : https://zakon.rada.gov.ua/laws/show/514-58\%D0\%BF\#Text. (дата звернення: 11.12.2020)

19. Конституція (Основний Закон) України від 20.04.1978 p. URL : https://zakon.r ada.gov.ua/laws/show/888-09\#Text. (дата звернення: 11.11.2020)

20. Основи житлового законодавства Союзу РСР і союзних республік від 24.06 .1981 № 5150-X. URL: https:/ /zakon.rada.gov.ua/laws/show/v5150400-81\#Tеxt. (дата звернення: 11.11.2020)

21. Науково-практичний коментар Житлового кодексу України станом на 2 вересня 2020 року ; за заг. ред. Журавльова Д. В. Київ : Професіонал, 2020.300 с.

\section{References:}

1. Orhanizatsiino-ekonomichni osnovy formuvannia ta rozvytku rynku dostupnoho 
zhytla: monohrafiia. (2010) S. A. Ushatskyi, A. V. Serdiuk (Eds.). Vinnytsi a: VNTU. [in Russian].

2. Hara,t M. Henezys mistobudivnoho zakonodavstva Ukrainy. (2019) Zovnishnia torhivlia: ekonomika, finansy, pravo - Foreign trade: economics, finance, law, 5, 101-116. URL: http:// nbuv.gov.ua/UJRN/uazt_2019_5_11. [in Russian].

3. Avramova, O. Ye. (2012) Istorychni zasady vynyknennia zhytlovoho prava Ukrainy. Visnyk Luhanskoho derzhavnoho universytetu vnutrishnikh sprav imeni E. Didorenka - Bulletin of Luhansk State University of Internal Affairs named after E.A. Didorenko, issue 4, 24-32. URL : http:// nbuv.gov.ua/UJRN/Vlduvs_2012_4_5. [in Russian].

4. Teremetskyi, V. I. (2017) Problemy pravovoho zabezpechennia vidnosyn u sferi opodatkuvannia zhytlovoi nerukhomosti. Vcheni zapysky Tavriiskoho natsionalnoho universytetu imeni $V$. I. Vernadskoho. Seriia: Yurydychni nauky - Scientific notes of Tavriya National University named after V. I. Vernadsky. Series: Legal Sciences, vol. 28 (67), 1, 47-57. [in Ukrainian].

5. Borysova K. S. (2018) Konstytutsiini zasady zabezpechennia prava na zhytlo v Ukraini. Extended adstract of candidate's thesis. Kyiv. [in Ukrainian].

6. Dekret VTsIK «Ob otmene prava chastnoi sobstvennosti na nedvizhimost $\mathrm{v}$ gorodakh» vid 20.08.1918 r. (2018) N. p. URL : http:/ /www.economics.kiev.ua/download/ZakonySSSR/ data04/tex17323.htm. [in Russian].

7. Ustav stroitelnyi, izmenennyi po prodolzheniiam 1876 i 1879 gg., s razieiasneniiami po resheniiam Ugolovnogo kassatsionnogo departamenta Pravitelstvuiushchego Senata i prilozheniem tsirkuliarov Ministerstva vnutrennikh del i pozdneishikh uzakonenii. Izd. 3. [S.-Peterburg] : Tipografiia pridv. knigopr. K. K. Retgera, 1881. [2], 428, V s.; 17. (1881) URL : http: //tehne.com/library/ustav-stroitelnyy-izdanie-trete-s-peterburg-1881. [in Russian].

8. Postanovlenie TsIK SSSR, SNK SSSR ot 19.08.1924 «O zhilishchnoi kooperatsii». (1924) N. p. URL : http://www.consultant.ru/cons/cgi/online.cgi?req=doc\&base=ESU\&n=3035\#04 7581929410741197. [in Russian].

9. Postanovlenie TsIK SSSR, SNK SSSR ot 04.01.1928 «O zhilishchnoi politike». (1928) N. p. URL : http://www.consultant.ru/cons/cgi/online.cgi?rnd=0F55ADDE8102A4094DDCB747 A1AD1A49\&req=doc\&base=ESU\&n=14332\&REFFIELD=134\&REFDST=100010\&REFDOC $=$ 11827\&REFBASE $=$ ESU\&stat $=$ refcode\%3D10679\%3Bindex\%3D17\#1drqg7kv3lq. [in Russian].

10. PostanovlenieSNKSSSR ot 17.04.1928 (v red. ot 14.09.1928 r.) «O merakh pooshchreniia stroitelstva zhilishch za schet chastnogo kapitala». (1928) N. p. URL : http:/ /www.consultant. $\mathrm{ru} / \mathrm{cons} / \mathrm{cgi} /$ online.cgi?rnd=0F55ADDE8102A4094DDCB747A1AD1A49\&req=doc\&base=ES U\&n=49115\&REFFIELD=134\&REFDST $=100011 \&$ REFDOC $=11827 \& R E F B A S E=E S U \& s t a t=r e f c$ ode\%3D19025\%3Bindex\%3D18\#2h6xj0lcv3g. [in Russian].

11. Iz istorii razvitiia smetnogo normirovaniia v Rossii. N. d. N. p. URL : https://avismedia.com/informatsiya/stati/stroitelstvo-i-smetnoe-delo/tsenoobrazovanie-i-smetnoe-nor mirovanie/iz-istorii-razvitiya-smetnogo-normirovaniya-v-rossii/. [in Russian].

12. Postanovlenie SNK SSSR ot 26.02.1938 № 233 «Ob uluchshenii proektnogo i smetnogo dela i ob uporiadochenii finansirovaniia stroitelstva» (vmeste s «Instruktsiei po sostavleniiu proektov i smet po promyshlennomu stroitelstvu», «Pravilami finansirovaniia stroitelstva promyshlennym bankom», «Pravilami o podriadnykh dogovorakh po stroitelstvu»). (1938) N. p. URL : http:// www.consultant.ru/cons/cgi/online.cgi?rnd=0F55ADDE8102A4094D DCB747A 1AD1A49\&req $=$ doc $\&$ base $=E S U \& n=32323 \&$ REFFIELD $=134 \&$ REFDST $=100004 \&$ REFDOC $=338$ 41\&REFBASE=ESU\&stat=refcode\%3D16876\%3Bindex\%3D11\#4xkc354aan8. [in Russian].

13. Kvasnitska, O. O. (2012) Istorychnyi rozvytok ta stanovlennia budivelnoho zakonodavstva u pravovomu dosvidi Ukrainy. Naukovi pratsi Natsionalnoho universytetu "Odeska yurydychna akademiiam" - Scientific works of the National University "Odessa Law Academy", vol. 12, 370-382. URL: http://nbuv.gov.ua/UJRN/Nponyua_2012_12_39. [in Ukrainian]. 
14. Konstytutsyiia (Osnovnyi Zakon) Ukrainskoi Radianskoi Sotsialistychnoi Respubliky vid 30.01.1937 r. (1937) N. p. URL : http://gska2.rada.gov.ua/site/const/istoriya/1937.html. [in Ukrainian].

15. Tyshkivska, N. (2007) (Vol. 1-4; Vol. 4). Osoblyvosti derzhavnoho upravlinnia zhytlovym budivnytstvom v URSR (1950-1960 roky). Stratehiia reformuvannia systemy derzhavnoho upravlinnia na zasadakh demokratychnoho vriaduvannia: materi. nauk.-prakt. konf. za mizhnar. uchastiu (Kyiv, 31 trav. 2007 r.). - Strategy for reforming the system of public administration on the basis of democratic governance: mothers. scientific-practical conf. for international. participation (Kyiv, May 31, 2007). Kyiv: Vyd-vo NADU, vol. 1, 169-171. [in Ukrainian].

16. Postanovlenie TsK KPSS, Sovmina SSSR ot 31.07.1957 № 931 «O razvitii zhilishchnogo stroitelstva v SSSR». (1957) N. p. URL : http:/ / docs.cntd.ru/document/765714291. [in Russian].

17. Postanova TsK Kompartii Ukrainy i Rady Ministriv URSR vid 24.08.1957 r. \# 988. (1957) N. p. Zibrannia postanov URSR - Collection of resolutions of the USSR, 12, art. 154. [in Ukrainian].

18. Postanova RM Ukrainskoi RSR «Pro zatverdzhennia Polozhennia pro zhytlovobudivelni kolektyvy ta indyvidualnykh zabudovnykiv u mistakh i selyshchakh miskoho typu Ukrainskoi RSR» vid 30.04.1958 №514. (1958) N. p. URL : https://zakon.rada.gov.ua/laws/ show/514-58-\%D0\%BF\#Text. [in Ukrainian].

19. Konstytutsiia (Osnovnyi Zakon) Ukrainy vid 20.04.1978 r. (1978) N. p. URL : https:// zakon.rada.gov.ua/laws/show/888-09\#Text. [in Ukrainian].

20. Osnovy zhytlovoho zakonodavstva Soiuzu RSR i soiuznykh respublik vid 24.06.1981 №5150-X. (1981) N. p. URL : https://zakon.rada.gov.ua/laws/show/v5150400-81\#Text. [in Ukrainian].

21. Naukovo-praktychnyi komentar Zhytlovoho kodeksu Ukrainy stanom na 2 veresnia 2020 roku. (2020) Zhuravlova D. V. (Ed.) Kyiv : Profesional. [in Ukrainian].

Стаття надіӥшиа до редколегї̈ 12.11.2020

Тарасюк Ю. В., заслуженный юрист Украины, первый заместитель директора КП «Житлоинвестбуд - УКБ»

(г. Киев, Украина)

\section{ГЕНЕЗИС АДМИНИСТРАТИВНО-ПРАВОВОГО ОБЕСПЕЧЕНИЯ ЖИЛИЩНОГО СТРОИТЕЛЬСТВА В УКРАИНЕ (СО ВРЕМЕН СУЩЕСТВОВАНИЯ СССР И ПО НАСТОЯЩЕЕ ВРЕМЯ)}

Статья посвящена осуществлению историко-правового анализа становления и развития административно-правового обеспечения жилищного строительства в Украине со времен существования СССР по настоящее время. Обосновано, что за годы господства в Украине советского режима был сформирован достаточно разветвленную систему нормативно-правовых актов по вопросам строительства, которая состояла из общесоюзных и республиканских актов, некоторые из которых действуют и по сей день. Проведение анализа современного этапа развития административно-правового обеспечения соответствующей сферы было отмечено, что в настоящее время одним из ключевых вопросов, который предстоит решить украинской власти, является обеспечение осуществления система- 
тизации законодательства в строительной сфере, с целью его приведения в единую, согласованную систему с четко определенным стержневым отраслевым законом.

Ключевые слова: историко-правовой анализ, становление, развитие, административно-правовое обеспечение, жилищное строительство, СССР, независимость, Украина.

\section{Tarasyuk Yu., Honored Lawyer of Ukraine First Deputy Director of municipal enterprise «Zhytloinvestbud - UKB» \\ (Kyiv, Ukraine) \\ GENESIS OF ADMINISTRATIVE AND LEGAL PROVISION OF HOUSING CONSTRUCTION IN UKRAINE (SINCE THE EXISTENCE OF THE USSR TILL THE PRESENT DAY)}

It has been argued that an extensive system of regulatory acts on building construction issues was formed during the years of Soviet rule in Ukraine, which consisted of all-Union and republican acts. It has been noted that this period of housing construction development is ambiguous in general, since there was a significant intensification of the housing construction industry, on the one hand, which allowed to solve the problem of providing housing for the population, both new and by the way of reconstructing the old buildings. On the other hand, construction was carried out considering the needs of the planned economy and the social needs of the population were taken into account to a much lesser extent. At the same time, the republican acts, which were to develop the provisions of all-Union legal documents taking into account the peculiarities of living conditions and development in the respective regions, often duplicated the provisions of all-Union acts.

It has been clarified that a large number of regulatory acts of various legal force were adopted during the years of independence, which were assigned to define the conceptual and strategic principles of housing construction development in Ukraine, to establish the necessary legal principles and guarantees in this area, to regulate organizational, administration and technical aspects for implementing this building construction. It has been stated that each time, adopting new important regulatory acts on substantive and procedural issues in the field of building construction, the government emphasizes its desire to provide the most effective, efficient, transparent and understandable mechanism for public administration in this area, but in practice everything is not so well, because rule-making, organizational and institutional changes quite often and unsystematically occur, which leads to legislative conflicts, gaps and other shortcomings, which do not contribute to strengthening the rule of law in the studied area. It has been emphasized that one of the key issues to be addressed by the legislator under such circumstances, is to ensure the systematization of legislation in the building construction sector, in order to bring it into a single, coherent system with a clearly defined core sectoral Law.

Keywords: historical and legal analysis, formation, development, administrative and legal provision, housing construction, USSR, independence, Ukraine. 